\title{
MEMBANGUN KEKUATAN NILAI PERJANJIAN SYARIAH DALAM UPAYA MENINGKATKAN KINERJA KARYAWAN BANK SYARIAH DI INDONESIA
}

\author{
Ayus Ahmad Yusuf \\ Institut Agama Islam Negeri Syekh Nurjati Cirebon \\ Jalan Perjuangan, Kesambi, Kota Cirebon, 45132, Jawa Barat \\ E-mail:ayusayusuf@yahoo.co.id \\ Layaman \\ Institut Agama Islam Negeri Syekh Nurjati Cirebon \\ Jalan Perjuangan, Kesambi, Kota Cirebon, 45132, Jawa Barat \\ E-mail: layaman72@gmail.com \\ Wartoyo \\ Institut Agama Islam Negeri Syekh Nurjati Cirebon \\ Jalan Perjuangan, Kesambi, Kota Cirebon, 45132, Jawa Barat \\ E-mail:wartoyo10@gmail.com
}

\begin{tabular}{c|c|c}
\hline Received: & Revised: & Approved: \\
$13 / 03 / 2017$ & $27 / 11 / 2017$ & $04 / 12 / 2017$ \\
\hline
\end{tabular}

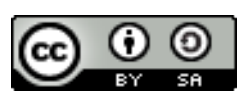

Membangun Kekuatan Nilai Perjanjian Syariah dalam Upaya Meningkatkan Kinerja Karyawan Bank Syariah di Indonesia is licensed under a Creative Commons Attribution-ShareAlike 4.0 International License.

\begin{abstract}
Abstrak
Penelitian ini dilatarbelakangi oleh adanya data empiris yang menunjukkan target pertumbuhan aset perbankan syariah dalam 5 tahun kebelakang tidak pernah tercapai. Berdasarkan data BI per Oktober 2014, total aset perbankan syariah baik Bank Umum Syariah (BUS) maupun Unit Usaha Syariah (UUS) mencapai Rp 260,36 triliun. Angka ini, hanya 4,78\% dari total aset perbankan konvensional yang bernilai Rp 5.445,65 triliun. Bahkan, pangsa aset perbankan syariah di akhir Oktober 2014 justru lebih sedikit jika
\end{abstract}


dibandingkan Oktober 2013 yang sebesar Rp 229,55 triliun atau 4,86\% dari total aset perbankan. BI pada akhir tahun 2013 menargetkan porsi aset bank syariah sebesar 5,25\%-6,25\% dari total aset bank umum konvensional. Hal ini salah satunya diindikasikan terjadi karena kapabilitas dan kompetensi karyawan bank syariah yang tidak mumpuni. Terbukti dari penelitian sebelumnya bahwa 70\% karyawan bank syariah bukan merupakan lulusan berbasis syariah, melainkan karyawan hasil mutasi dari bank konvensional induknya. Empat hipotesis dibangun untuk menyelesaikan masalah penelitian, dengan metode pengumpulan data purposive random sampling. Teknik analisis data yang digunakan adalah structural equational modeling yang menggunakan software AMOS 16. Berdasarkan hasil penelitian dihasilkan kesimpulan bahwa (1) Komitmen organisasi berpengaruh positif terhadap sharia engagement. (2) Komitmen organisasi tidak berpengaruh terhadap kinerja karyawan. (3) Kepemimpinan transformasional berpengaruh positif terhadap sharia engagement. (4) Kepemimpinan transformasional tidak berpengaruh terhadap kinerja karyawan dan (5) Sharia engagement berpengaruh positif terhadap kinerja karyawan.

Kata Kunci: Sharia Engagement, Bank Syariah, dan Kinerja Karyawan

\section{Abstract}

This research was motivated by the empirical data that shows the target growth of Islamic banking assets in 5 years back never reached. Based on BI data as of October 2014, the total assets of Islamic banking both Islamic Banks (BUS) and Sharia (UUS) reached $R p 260.36$ trillion. This figure, only $4.78 \%$ of the total assets of conventional banks are worth $\mathrm{Rp} 5445.65$ trillion. In fact, the share of Islamic banking assets at the end of October 2014 even less than in October 2013 from Rp 229.55 trillion, or $4.86 \%$ of total banking assets. BI at the end of 2013 targeting the portion of the assets of Islamic banks amounted to $5.25 \%-6.25 \%$ of the total assets of conventional banks. This is one of them indicated happen because of the capabilities and competence of employees of Islamic banks are not qualified. Evident from previous research that $70 \%$ of employees are graduates of Islamic banks is not based on sharia, but employees are the result of mutations of the parent conventional bank. Four hypotheses are built to solve the problem of research, data collection method purposive random sampling. Data analysis technique used is equational structural modeling using AMOS software 16. Based on the research produced the conclusion that (1) Commitment positive effect on sharia organization engagement.

(2) The commitment the organization has no effect on employee performance. (3) Transformational leadership has positive influence on sharia engagement. (4) 
Transformational leadership does not affect the performance of employees, and (5) Sharia engagement positively affects employee performance

Keywords: Engagement Sharia, Islamic Banking, and Employee Performance

\section{A. Pendahuluan}

Indonesia dengan penduduk Muslim terbesar di dunia memiliki potensi yang sangat besar untuk menjadi leader dalam industri keuangan dan perbankan syariah dunia. Namun, pada kenyataannya akselerasi dan penetrasi pertumbuhan perbankan syariah di Indonesia berjalan lamban, dari target proyeksi pada 2014 mampu menguasai setidaknya $6 \%$ pasar keuangan nasional.Realisasinya hingga akhir 2014 pertumbuhan perbankan syariah tidak lebih dari 4\% dari total industri perbakan nasional. Berdasarkan data BI per Oktober 2014, total aset perbankan syariah baik Bank Umum Syariah (BUS) maupun Unit Usaha Syariah (UUS) mencapai Rp 260,36 triliun. Angka ini, hanya $4,78 \%$ dari total aset perbankan konvensional yang bernilai Rp 5.445,65 triliun. Bahkan, pangsa aset perbankan syariah di akhir Oktober 2014 justru lebih sedikit jika dibandingkan Oktober 2013 yang sebesar Rp 229,55 triliun atau 4,86\% dari total aset perbankan. BI pada akhir tahun 2013 menargetkan porsi aset bank syariah sebesar $5,25 \%-6,25 \%$ dari total aset bank umum konvensional. ${ }^{1}$

Lambannya pertumbuhan perbankan syariah ini tentu disebabkan oleh banyak faktor, baik internal maupun eksternal seperti ; keterbatasan sumber daya manusia (SDM) yang handal, kurangnya keberpihakan pemerintah, minimnya sosialisasi dan masih banyak faktor-faktor lainnya. Dari semua faktor-faktor yang ada, bila diselidiki lebih dalam, ditengarai sumber daya manusia (SDM) merupakan salah satu faktor yang memiliki peraanan yang paling besar terhadap ketidakmampuan perbankan syariah mencapai target proyeksi setiap tahunnya. Hal ini bisa dilihat dari data-data sebagai berikut : Pertama, latar belakang pendidikan karyawan perbankan syariah di Indonesia baru 59\% yang mencapai tingkat pendidikan S1, sedangkan 21\% lainnya lulusan D3 dan 18\% sisanya hanya lulusan SMA dan sederajat. Kedua, dari 59\% lulusan S1 tersebut, hampir $90 \%$

${ }^{1}$ Bank Indonesia, “Outlook Perbankan Syariah 2014” dalam www.bi.go.id. diunduh pada 17 Maret 2014. 
memiliki latar belakang keilmuan ekonomi konvensional, sedangkan yang memiliki latar belakang keilmuan syariah hanya 10\%. Ketiga, hampir 70\% sumber daya manusia perbankan syariah merupakan pegawai yang dimutasi dari bank induknya yang konvensional, sedangkan $20 \%$ merupakan fresh graduate dan 10\% lainnya dari bankbank syariah dan lainnya².

Melihat data ketersediaan dan kompetensi sumber daya manusia di atas, maka sudah seharusnya perbankan syariah melakukan evaluasi terhadap kebijakan dan strategi dalam pengembangan dan pembangunan kualitas SDM-nya. Sebab tanpa SDM yang mumpuni dan handal di bidangnya, akan terasa mustahil perbakan syariah di Indonesia dapat mencapai target pertumbuhan yang diharapkan. Dari data tersebut juga perbankan syariah dipandang perlu melakukan suatu strategi dalam bentuk penguatan nilai sharia engagement untuk meningkatkan kualitas dan kapabilitas sumber daya manusianya.

Hal ini dipandang sangat penting dan mendesak, dikarenakan sampai saat ini masih terjadi sinisme maupun skeptisme dari masyarakat Muslim sendiri dalam memandang dan menilai kinerja SDM di perbankan syariah yang masih terasa sangat konvensional. Sehingga bagi mereka tidak ada bedanya antara bertransaksi di bank syariah atau di bank konvensional, sebab yang membedakan hanya sebatas "jilbab" dan "salam" saja.

Sebagai perbandingan di Malaysia, dari sisi sumber daya manusia (SDM) mereka memiliki lembaga yang bernama Centre for Education in Islamic Finance (INCEIF) dan Islamic Sharia Research Academy for Islamic Finance (ISRA) yang dikelola secara khusus oleh pemerintah untuk menjadi sumber penyuplai SDM yang berkualitas pada perbankan syariah di Malaysia. Di dua lembaga ini dididik dan didikumpulkan para pakar keuangan syariah dari seluruh negara bagian untuk melatih, mentraining, membedah dan merekomendasikan khususnya strategi pengembangan SDM keuangan syariah di Malaysia. Maka tidak mengherankan bila di

${ }^{2}$ Bank Indonesia. Statistis Perbankan Syariah 2010. diunduh dari www.bi.go. id. tanggal 16 April 2015. 
Malaysia perbankan syariah mampu tumbuh pesat hingga mencapai kisaran 20\% dari industri perbankan nasionalnya ${ }^{3}$.

Melihat data dan fakta tersebut, terlihat bahwa kualitas SDM adalah salah satu faktor kunci yang menyebabkan belum mampunya perbankan syariah di Indonesia berkembang secara signifikan. Maka diperlukan suatu keterlibatan kerja (engagement) antara pihak-pihak yang berkepetingan, terutama dalam hal ini adalah karyawan di bank-bank syariah.

Engagement (keterlibatan kerja) merujuk pada keterlibatan individu dan kepuasan dengan serta antusias untuk bekerja. Konsep ini dibangun oleh Kahn (1990), engagement menjelaskan keterlibatan intim dengan kerangka pengalaman kerja. Ketika karyawan terlibat, emosional karyawan akan terhubung dengan orang lain dan terhadap tim kerja. Keterlibatan terjadi ketika karyawan tahu apa yang diharapkan, memiliki sumber daya untuk menyelesaikan pekerjaan mereka, berpartisipasi dalam peluang untuk pertumbuhan dan umpan balik, dan merasa bahwa mereka memberikan kontribusi yang signifikan bagi organisasi ${ }^{4}$.

Sementara itu, konsep Sharia engagement pertama kali dikembangkan oleh Rusdianti (2013), yaitu keterikatan individu dalam organisasi baik secara fisik, emosional maupun spiritual yang dilandasi oleh keyakinan, keadilan/keseimbangan, kebebasan dan tanggungjawab. Sharia engagement ini berpotensi meningkatkan kinerja karyawan. Konsep syariah pada engagement dikaji melalui a). Karakteristik organisasi yang berbeda dalam hal ini adalah yang berdasarkan syariah. b) Norma sosial dan etika islam yang sudah tergeneralisasi dan menjadi acuan individu - individu dalam organisasi untuk bertindak yaitu keyakinan, keadilan/keseimbangan, kebebasan dan tanggung jawab. c). Rasa kebersamaan yang diupayakan organisasi antar pimpinan, antar karyawan maupun nasabah berdasarkan prinsip syariah d).

\footnotetext{
${ }^{3}$ Ibrahim Aji, "Haruskah Kita Meniru Malaysia?" dalam Majalah Majalah Sharing, Edisi 85 Tahun VIII Juni-Juli 2014, 10

${ }^{4}$ Harter, J. K., Schmidt, F. L., \& Hayes, T. L. Business-unit-level relationship between employee satisfaction employee engagement, and business outcomes: (A metaanalysis. Journal of Applied Psychology, 2002) h. 87, 268-279. Diunduh pada tanggal 20 Maret 2015 dari www. psycnet.apa.org
} 
Kepercayaan masyarakat terhadap organisasi yang implikasinya nampak dari semakin banyaknya kantor cabang yang tumbuh ${ }^{5}$. Untuk itu kiranya akan menarik untuk dilakukan penelitian mengenai sharia engagement dalam meningkatkan kualitas kinerja karyawan di bank syariah.

Penelitian ini bertujuan (1) Untuk mengetahui pengaruh komitmen organisasional terhadap sharia engagement. (2) Untuk mengetahui pengaruh kepemimpinan tranformasional terhadap sharia engagement. (3) Untuk mengetahui pengaruh komitmen organisasional terhadap kinerja karyawan. (4) Untuk mengetahui pengaruh kepemimpinan tranformasional terhadap kinerja karyawan. (5) Untuk mengetahui apakah sharia enggement berpengaruh positif terhadap kinerja karyawan.

\section{B. Kajian Pustaka dan Pengembangan Hipotesis \\ 1. Komitmen organisasional, Sharia Engagement dan Kinerja Karyawan}

Komitmen organisasional dikembangkan oleh Allen dan Meyer pada tahun 1991, adalah refleksi perasaan seseorang terhadap organisasinya, pengakuan tentang harga yang harus dibayar bila meninggalkan organisasi dan tanggung jawab moral untuk tetap berada dalam organisasi. Sedangkan Albdour, A. A., \& Altarawneh, I. I. (2014) mengemukakan bahwa komitmen adalah kekuatan relatif dari identifikasi individu kaitannya dengan engagement dalam organisasi. ${ }^{6}$ Richard M. Steers mendefinisikan komitmen organisasional sebagai rasa identifikasi (kepercayaan terhadap nilainilai organisasi), sehingga tercipta engagement (kesediaan untuk berusaha sebaik mungkin demi kepentingan organisasi) dan loyalitas (keinginan untuk tetap menjadi anggota organisasi yang bersangkutan) yang dinyatakan oleh seorang pegawai terhadap organisasinya. ${ }^{7}$

${ }^{5}$ Rusdianti, E. Membangun Pertautan Syariah Kaitannya Dengan Peningkatan Kinerja Karyawan. (Disertasi, 2013 Universitas Diponegoro, Semarang) h. 124-127

6 Albdour, A. A., \& Altarawneh, I. I. (2014). Employee engagement and organizational commitment: Evidence from Jordan. International Journal of Business, 19(2), 192.

7 Murty, W. A., \& Hudiwinarsih, G. (2012). Pengaruh kompensasi, motivasi dan komitmen organisasional terhadap kinerja karyawan bagian akuntansi 
Semakin tinggi komitmen karyawan menjadi bagian dari organisasi, semakin besar kemungkinan mereka untuk tetap dengan organisasi. Sharia engagement pertama kali dikembangkan oleh Rusdianti, E (2013), yaitu keterikatan individu dalam organisasi baik secara fisik, emosional maupun spiritual yang dilandasi oleh keyakinan, keadilan/keseimbangan, kebebasan dan tanggungjawab. Sharia engagement ini berpotensi meningkatkan kinerja karyawan. Konsep syariah pada engagement dikaji melalui a). Karakteristik organisasi yang berbeda dalam hal ini adalah yang berdasarkan syariah. b) Norma sosial dan etika islam yang sudah tergeneralisasi dan menjadi acuan individuindividu dalam organisasi untuk bertindak yaitu keyakinan, keadilan/keseimbangan, kebebasan dan tanggung jawab. c). Rasa kebersamaan yang diupayakan organisasi antar pimpinan, antar karyawan maupun nasabah berdasarkan prinsip syariah d). Kepercayaan masyarakat terhadap organisasi yang implikasinya nampak dari semakin banyaknya kantor cabang yang tumbuh.

Berbagai penelitian menunjukkan bahwa komitmen organisasi meningkatkan keterlibatan karyawan dalam bekerja, semakin tinggi komitmen organisasi semakin kuat engagement (Albdour, A. A., \& Altarawneh, I. I. (2014), meningkatkan usaha, dedikasi, kerjasama, tanggung jawab, hubungan sosial, kreativitas dan engagement dan kesiapan akan perubahan. ${ }^{8}$

Berdasarkan hasil penelusuran tersebut, maka hipotesis yang dikembangkan adalah :

H1: Komitmen organisasional berpengaruh positif terhadap sharia engagement

Komitmen dianggap penting bagi organisasi karena : (1) Pengaruhnya pada turn over. (2) Hubungannya dengan kinerja yang mengasumsikan bahwa individu yag memiliki komitmen cenderung mengembangkan upaya yang lebih besar pada

(studi kasus pada perusahaan manufaktur di Surabaya). The Indonesian Accounting Review, 2(02), 215-228.

${ }^{8}$ Mangundjaya, W. L. (2012). are organizational commitment and employee engagement important in achieving individual readiness for change?.humanitas (Jurnal Psikologi Indonesia), 9(2). 
pekerjaaan. ${ }^{9}$ Komitmen organisasional memegang peranan penting bagi peningkatan kinerja ${ }^{10}$. Komitmen organisasional dibedakan atas tiga komponen, yaitu a). Komponen afektif keterikatan emosional karyawan, identifikasi dan keterlibatan karyawan di dalam suatu organisasi, b). Komponen normatif merupakan perasaanperasaan karyawan tentang kewajiban yang harus ia berikan kepada organisasi, c). Komponen continuance/kelanjutan berarti komponen berdasarkan persepsi karyawan tentang kerugian yang akan dihadapi jika ia meninggalkan organisasi. ${ }^{11}$

Berbagi hasil penelitian mendukung bahwa komitmen organisasi yang kuat akan meningkatkan kinerja karyawan bagian akuntansi (Murty, W. A., \& Hudiwinarsih, G., 2012), kinerja auditor inspektorat (Sujana, E. (2012), berperan untuk peningkatan kinerja (Melina Taurisa, C., \& Intan, R. (2012) dan merupakan ukuran penting dari keefektifan organisasi dan berhubungan positif dengan kinerja karyawan. ${ }^{12}$ Berdasarkan uraian di atas, maka dapat dirumuskan hipotesis sebagai berikut:

H2: Komitmen organisasional berpengaruh positif terhadap kinerja kayawan

\section{Kepemimpinan Transformasional, Sharia Engagement dan Kinerja Karyawan}

Bass, pada tahun 1985 mengembangkan kepemimpinan transformasional sebagai proses yang terjadi ketika satu atau lebih orang terlibat dengan orang lain sedemikian rupa sehingga pemimpin dan pengikut meningkatkan satu sama lain untuk tingkat yang lebih tinggi motivasi dan moralitas. Empat dimensi kepemimpinan transformasional adalah: (1) idealized influence, yang berkaitan dengan

${ }^{9}$ Sujana, E. (2012). Pengaruh Kompetensi, Motivasi, Kesesuaian Peran Dan Komitmen Organisasi Terhadap Kinerja Auditor Internal Inspektorat Pemerintah Kabupaten (Studi Pada Kantor Inspektorat Kabupaten Badung Dan Buleleng). JINAH (Jurnal Ilmiah Akuntansi dan Humanika), 2(1)..

${ }^{10}$ Ibid... Murty, W. A., \& Hudiwinarsih, G.

${ }^{11}$ Mowday, R. T., Porter, L. W., \& Steers, R. M. (2013). Employee - organization linkages: The psychology of commitment, absenteeism, and turnover. Academic press..

12 Murty, W. A., \& Hudiwinarsih, G. (2012). Pengaruh kompensasi, motivasi dan komitmen organisasional terhadap kinerja karyawan bagian akuntansi (studi kasus pada perusahaan manufaktur di Surabaya). The Indonesian Accounting Review, 2(02), 215-228. 
membangun keyakinan dan kepercayaan; (2) inspirational motivation, yang berkaitan dengan memotivasi seluruh organisasi; (c) intellectual stimulation, yang melibatkan membangkitkan kesadaran dan mengubah pengikut untuk memecahkan masalah dengan kemampuan mereka; dan (d) individualized consideration, yang melibatkan merespon, kebutuhan unik spesifik pengikut untuk memastikan mereka termasuk dalam proses transformasi organisasi. Keempat dimensi memungkinkan pemimpin untuk berperilaku teladan yang kuat mendorong transformasi pengikut $<$ menjadi individu yang lebih sukses dan produktif. Kepemimpinan transformasional muncul sebagai gaya yang mendorong perkembangan keterlibatan karyawan.

Pemimpin transformasional memberikan visi yang menginspirasi tujuan yang dapat membantu mengatasi kepentingan diri sendiri dan faksionalisme sempit dalam organisasi. Tipe kepemimpinan ini memberi energi baru dan lebih luas di kalangan pengikut. Breevaart, K., Bakker, A., Hetland, J., Demerouti, E., Olsen, O. K., \& Espevik, R. (2014) menemukan bahwa karyawan yang memiliki interaksi positif dengan manajer mereka dapat meningkatkan keterlibatan kerja. ${ }^{13}$ Dalam studi yang lain Breevaart, K., Bakker, A. B., Demerouti, E., Sleebos, D. M., \& Maduro, V. (2014) menemukan bahwa para pemimpin yang fokus pada membangun hubungan dan kepercayaan meningkatkan tingkat keterlibatan. Pemimpin transformasional tidak dipandang sebagai sosok kekuasaan tetapi sebagai saling mendukung untuk tujuan yang sama, baik kolektif organisasi. ${ }^{14}$ Dari perspektif ini, pemimpin transformasional memiliki kapasitas untuk langsung berdampak pada tingkat keterlibatan karyawan mereka dan mampu memenuhi kebutuhan manusia dan kerja karyawan mereka, dividen yang sangat unik dan memberdayakan karyawan. ${ }^{15}$

13 Breevaart, K., Bakker, A., Hetland, J., Demerouti, E., Olsen, O. K., \& Espevik, R. (2014). Daily transactional and transformational leadership and daily employee engagement. Journal of occupational and organizational psychology, 87(1), 138- 157.

${ }^{14}$ Breevaart, K., Bakker, A. B., Demerouti, E., Sleebos, D. M., \& Maduro, V. (2014). Uncovering the underlying relationship between transformational leaders and followers' task performance. Journal of Personnel Psychology.

${ }^{15}$ Nohria, N., Groysberg, B., \& Lee, L. (2008). Employee motivation: A powerful new model. Harvard Business Review, 86, 78-84. Diunduh dari: www. homeworkmarket.com tanggal 15 April 2015. 
Karyawan yang memiliki interaksi positif dengan manajer mereka dapat meningkatkan keterlibatan kerja ${ }^{16}$, pemimpin yang fokus pada membangun hubungan dan kepercayaan meningkatkan tingkat keterlibatan, ${ }^{17}$ pemimpin transformasional memiliki kapasitas untuk langsung berdampak pada tingkat keterlibatan karyawan mereka ${ }^{18}$ dan semua aspek kepemimpinan transformasional yang dipraktekkan oleh manajer mengarah ke keterlibatan kerja karyawan yang lebih tinggi. ${ }^{19}$ Berdasarkan hasil penelusuran tersebut, maka hipotesis yang dikembangkan adalah :

H3: Kepemimpinan transformasional berpengaruh positif terhadap sharia engagement

Kepemimpinan dianggap sebagai faktor yang memiliki pengaruh besar terhadap kinerja organisasi, manajer dan karyawan. ${ }^{20}$ Hubungan antara kepemimpinan dan kinerja telah mendapat perhatian ilmiahyang sangat luas. Kebanyakan penelitian tentang hubungan antara kepemimpinan transaksional dan kinerja organisasi telah menghasilkan temuan mengecewakan. Namun, ketika Bass (1985) dengan menggunakan Multifactor Leadership Questionnaire (MLQ), menemukan korelasi yang tinggi antara gaya kepemimpinan transformasional dan tingkat kinerja organisasi. Korelasi ini secara konsisten lebih tinggi dari gaya kepemimpinan transaksional. ${ }^{21}$

Berbagai penelitian juga mendukung pendapat Bass, kepemimpinan transformasional berpengaruh terhadap kinerja tugas

${ }^{16}$ Ibid...Bakker, A. B., E Schaufeli.

${ }_{17}$ Ibid... Cartwright, S., \& Holmes.

${ }_{18}$ Ibid.... Nohria, N., Groysberg, B., E Lee

19 Raja, M.W. (2012). Does Transformational Leadership Leads To Higher Employee Work Engagement, A Study of Pakistani Service Sector Firms. International Journal of Academic Research in Business and Social Sciences, Vol. 2, No. 1. Diunduh dari: http://www.hrmars.com/tanggal 11 Maret 2015.

20 Wang, G., Oh, I. S., Courtright, S. H., \& Colbert, A. E. (2011). Transformational leadership and performance across criteria and levels: A metaanalytic review of 25 years of research. Group \& Organization Management, 36(2), 223- 270.

${ }^{21}$ Dumdum, U. R., Lowe, K. B., \& Avolio, B. J. (2013). A meta-analysis of transformational and transactional leadership correlates of effectiveness and satisfaction: An update and extension. In Transformational and Charismatic Leadership: The Road Ahead 10th Anniversary Edition (pp. 39-70). Emerald Group Publishing Limited.. 
karyawan, ${ }^{22}$ kinerja karyawan, ${ }^{23}$ kinerja organisasi ${ }^{24}$ dan terhadap kinerja pelayanan. ${ }^{25}$ Berdasarkan hasil penelusuran tersebut, maka hipotesis yang dikembangkan adalah:

\section{H4 : Kepemimpinan transformasional berpengaruh positif terhadap kinerja karyawan.}

Semakin populernya penggunaan konsep employee engagement dalam praktik disebabkan karena ada kesepakatan umum mengenai dampak positif dan signifikan dari employee engagement dalam kinerja organisasi dan hasil bisnis. Engagement karyawan adalah prediktor kuat dan positif dari kinerja karyawan, ${ }^{26}$ engagement karyawan akan mengarah ke peningkatan yang lebih tinggi dari kinerja, ${ }^{27}$ hubungan positif antara engagement dan kinerja individu ${ }^{28}$ dan merupakan pendorong peningkatan kinerja. ${ }^{29}$ Berdasarkan uraian di atas, maka dapat dirumuskan hipotesis sebagai berikut:

${ }^{22}$ Cavazotte, F., Moreno, V., \& Bernardo, J. (2013). Transformational leaders and work performance: The mediating roles of identification and self-efficacy. BAR Brazilian Administration Review, 10(4), 490-512. Diunduh dari http://doi.org/tanggal 24 Maret 2015.

${ }^{23}$ Sundi, K. (2013). Transformational Leadership and Transactional Leadership on Employee Performance of Konawe Education Department at Southeast Sulawesi Province. International Journal of Business and Management Invention, Vol. 2 no.12, p. 50-58. Diunduh dari http://www.ijbmi.org/tanggal 02 April 2015.

${ }^{24}$ De Jong, S. B., \& Bruch, H. (2013). the Importance of a Homogeneous Transformational Leadership Climate for Organizational Performance. International Journal of Leadership Studies, 8(1), 1-18. Diunduh dari http:/ / search.ebscohost.com/ tanggal 02 Maret 2015

${ }^{25}$ Weng, L., Su, C., \& Lai, Y. (2011). Superior Service Performance through Transformational Leadership : A Cross-level Study of a Large Taiwanese Commercial Bank. Asia Pacific Management Review, Vol. 16(2), 181-195. Diunduh dari http://doi. org/tanggal 12 Maret 2015.

${ }^{26}$ Solomon Markos and M. Sandhya Sridevi. (2010). EmployeeEngagement: The Key to Improving Performance. International Journal of Business and Management. Diunduh dari: http:/ / www.ccsenet.org/tanggal 16 Maret 2015.

27 Macey, W. at all (2009), Employee engagement: Tools for analysis, practice, and competitive advantage, Personnel Psychology, Volume 65, Issue 1, pages 207-210, Spring 2012. Diunduh dari: http://onlinelibrary.wiley.com/tanggal 17 April 2015.

${ }^{28}$ Xanthopoulou, D., Bakker, A. B., Heuven, E., Demerouti,E., \& Schaufeli, W. B. (2008). Working in the sky: A diary study on work engagement among flight attendants. Journal of Occupational Health Psychology, Vol. 13, No. 4, 345-356. Diunduh dari: http://repub.eur.nl/pub/tanggal 10 April 2015.

${ }^{29}$ Jamie A. Gruman Alan M. Saks. (2009). Performance management and employee engagement, Human Resource Management Review, 21 (2011), 123-136. Diunduh dari: www.sciendirect.com tanggal 10 April 2015. 
H5: Sharia Engagement berpengaruh positif terhadap kinerja kayawan

\section{Metode Penelitian}

\section{Populasi dan sampel}

Populasi adalah gabungan dari seluruh elemen yang berbentuk peristiwa, hal atau orang yang memiliki karakteristik serupa yang menjadi pusat perhatian seorang peneliti karena dipandang sebagai sebuah semesta penelitian ${ }^{30}$. Populasi dari penelitian ini adalah seluruh karyawan Bank Syari'ah se wilayah III Cirebon. Sampel adalah subset dari populasi, terdiri dari beberapa anggota populasi. Sampel pada penelitian ini diambil dengan metode purposive sampling. Jumlah sampel dalam penelitian ini diambil dengan pertimbangan bahwa analisis data yang digunakan adalah SEM. Seperti yang dikemukakan Ferdinand (2011) dalam pengujian model SEM yang sensitif terhadap sampel dibutuhkan sampel yang baik berkisar antara 100-200 sampel. Dalam penelitian ini jumlah sampel yang dianalisis sebanyak 137 sampel, sehingga jumlah ini masih berada pada ukuran kecukupan sampel.

\section{Pengukuran variabel}

Penelitian ini merupakan penelitian terapan (field research) dengan menggunakan metode pendekatan kuantitatif. Objek penelitian dalam penelitian ini tentang komitmen organisasi, kepemimpinan transformasional, Sharia engagement dan Kinerja karyawan. Pengukuran variabel penelitian dilakukan dengan skala 1-10, dimana 1 menunjukkan "sangat tidak setuju" dan 10 menunjukkan "sangat setuju".

Komitmen organisasional adalah suatu refleksi perasaan seseorang terhadap organisasinya, pengakuan tentang imbalan yang harus dibayar bila meninggalkan organisasi dan tanggungjawab moral untuk tetap berada dalam organisasi ${ }^{31}$. Indikator

${ }^{30}$ Ferdinand, A . Metode Penelitian Manajemen; Pedoman Penelitian Untuk Penulisan Skripsi, Tesis dan Disertasi Ilmu Manajemen, (Semarang: Badan Penerbit UNDIP, 2011) h. 215.

${ }^{31}$ Allen, Natalie J and Meyer, John P, The Measurement And Antecedents Of Affective, Countinuance And Normative Commitment To Organization, (Journal of 
komitmen organisasional: Bangga pada organisasi, pertimbangan kerugian apabila keluar dari organisasi dan beban moral apabila meninggalkan organisasi.

Kepemimpinan transformasional didefinisikan sebagai kepemimpinan yang membutuhkan tindakan memotivasi para bawahan agar bersedia bekerja demi sasaran-sasaran tingkat tinggi yang dianggap melampaui kepentingan pribadinya pada saaat itu. ${ }^{32}$ Dengan indikator: tindakan memberi contoh, tindakan memberi inspirasi, tindakan memberi dorongan memecahkan dan tindakan memberi perhatian kepada bawahan.

Sharia Engagement merupakan keterikatan individu dalam organisasi baik secara fisik, emosional maupun spiritual yang dilandasi oleh keyakinan, keadilan/keseimbangan, kebebasan \&tanggungjawab. Dengan indikator: Etos kerja, kebebasan yang bertanggung jawab, kesadaran tentang keyakinan atas pengawasan dan titah Tuhan, keadilan/keseimbangan, sholat tepat waktu, puasa sunah senin-kamis, melaksanakan zakat, infak dan shodaqoh serta mengawali dan mengakhiri pekerjaan dengan do'a.

Kinerja karyawan adalah hasil kerja secara kualitas dan kuantitas yang dicapai oleh seorang karyawan dalam melaksanakan tugasnya sesuai dengan tanggung jawab sesuai standar mutu, sesuai dengan wewenang dan tanggung jawab, secara legal, tidak melanggar hukum dan moral maupun etika ${ }^{33}$. Dengan indikator: kualitas kerja (quality of work), keikhlasan (cooperative), niat melayani (initiative) dan kejujuran (personal qualities).

Untuk menguji model dan hipotesis digunakan analisis SEM. Dalam pengujian model dengan menggunakan SEM, terdapat tujuh langkah yang ditempuh, yaitu (1) Pengembangan model berbasis teori, (2) Pengembangan diagram alat untuk menunjukkan hubungan kausalitas, (3) Mengkonversikan diagram alur ke dalam persamaan, (4) Pemilihan matriks input dan teknik estimasi atas model yang

Occupational Psychology, 1990). h. 1-18. Diunduh pada tanggal 03 April 2015 dari http://scholar.google.co.id/scholar.

${ }^{32}$ Bass, B. M.. Leadership and performance beyond exceptions. (New York: Free Press.1985), 225

${ }^{33}$ Bernadin, H. John and Joyce E.A Russel, Human Resources Management, (Mc.Graw Hill, Inc. Singapore, 1993), 312 
dibangun, (5) Menilai problem identifikasi, (6) Evaluasi modeldan (7) Interpretasi dan modifikasi model.

Sebelum digunakan untuk mengumpulkan data di lapangan, kuesioner diuji validitas dan reliabilitasnya. Dengan menggunakan instrumen yang valid dan reliabel dalam pengumpulan data, maka diharapkan hasil penelitian akan valid dan reliabel. Instrumen yang valid dan reliabel merupakan syarat mutlak untuk mendapatkan hasil penelitian yang valid dan reliabel. Validitas menunjukkan sejauh mana suatu alat ukur dapat mengukur apa yang diukur. Validitas dalam penelitian dijelaskan sebagai suatu derajat ketepatan alat ukur penelitian tentang isi atau arti sebenarnya yang diukur. Sedangkan reliabilitas digunakan untuk mengetahui sejauhmana instrumen pengukur dapat dipercaya atau dapat diandalkan. Reliabilitas adalah derajat ketepatan, ketelitian atau keakuratan yang ditunjukkan oleh instrumen pengukuran ${ }^{34}$.

\section{Hasil Penelitian}

\section{Hasil Analisis Statistik Deskriptif}

Responden pada penelitian ini adalah karyawan perbankan syariah yang dan berlokasi di wilayah III Cirebon, yang meliputi Kota dan Kabupaten Cirebon, Kabupaten Indramayu, Kabupaten Majalengka dan Kabupaten Kuningan. Peneliti mendatangi langsung disemua kantor cabang dan kantor cabang pembantu untuk menyebarkan kuesioner. Kuesioner disebarkan setelah peneliti mendapat ijin dari pimpinan cabang atau pimpinan KCP. Penyebaran dan pengumpulan kuesioner dilakukan selama satu bulan yaitu mulai dari awal bulan Oktober sampai akhir Oktober 2015.

Penelitian ini dilakukan dengan menyebarkan 300 kuesioner yang dialokasikan secara proporsional. Kuesisoner yang kembali sebanyak 170 kuesioner. Setelah dilakukan pengecekan ada sebanyak 15 kuesioner yang cacat dan 18 kuesioner dikategorikan sebagai outlier. Sehingga jumlah total kuesioner yang dianalisis sebanyak 137 kuesioner.

${ }^{34}$ Sugiono, Statitika untuk Penelitian, (Bandung: Alfabeta, 2012) h. 352 


\section{Gambaran Umum Responden}

Gambaran umum dari responden dalam penelitian ini memberikan deskripsi responden berdasarkan jenis kelamin, tingkat pendidikan, umur, masa kerja dan pengalaman kerja sebelumnya dari responden. Berdasarkan jenis kelamin, responden laki-laki berjumlah $61,86 \%$ dari total sampel, sedangkan responden perempuan berjumlah $38,14 \%$ dari total sampel. Dilihat dari sisi umur, responden dengan dengan umur antara 20-25 tahun berjumlah $16,10 \%, 25-29$ tahun berjumlah 55,08\%, 30-40 tahun berjumlah $24,58 \%$ dan responden dengan umum lebih dari 40 tahun berjumlah 4,24\%. Untuk tingkat pendidikan responden, $16,95 \%$ berpendidikan D3, $81,36 \%$ berpendidikan S1 dan 1,69\% berpendidikan S2. Sedangkan bila dilihat dari klasisfikasi pendidikannya, 93,22\% merupakan lulusan perguruan tinggi umum dan hanya $6,78 \%$ yang berpendidikan ilmu ekonomi syariah. Dari segi pengalaman kerja, 75,42\% sudah bekerja antara $2-5$ tahun, 24,58\% telah bekerja lebih dari 5 tahun di perusahaannya masing-masing.

\section{Hasil Analisis Statistik Inferensi}

Sebelum data hasil penelitian digunakan untuk menuji model, langkah awal yang peneliti lakukan adalah melakukan penormalan terhadap data yang akan di analisis. Langkah ini dilakukan karena pengolahan data dengan SEM melalui sofware AMOS mempunyai asumsi persyaratan bahwa data yang akan dianalisis harus berdistribusi normal. Peneliti melakukan penormalan data dengan tiga teknik. Pertama, melakukan screening data dengan cara menghapus secara bertahap pada data-data yang mempunyai mahalanobis terbesar sehingga normalitas dapat tercapai ${ }^{35}$. Teknik ini dilakukan dengan pertimbangan bahwa nilai mahalanobis yang lebih besar dari nilai chi-square yang dipersyaratkan menunjukkan adanya outlier yang dapat mengganggu tercapainya sebaran data yang normal. Kedua, penormalan data dilakukan dengan teknik transformasi data. Transformasi data dilakukan dengan mempertimbangkan nilai skewness apakah bernilai positif atau negatif dan besaran nilainya apakah termasuk moderat, substansial atau sangat besar.

35 Imam Ghozali, Aplikasi Analisis Multivariate Dengan Program SPSS. (Semarang : BP Universitas Diponegoro, 2011), h. 145. 


\section{Uji Konfirmatori Faktor}

Setelah data terdistribusi normal, langkah selanjutnya yang peneliti lakukan adalah melakukan uji konfirmatori faktor untuk konstruk eksogen maupun konstruk endogen. Secara lebih rinci proses pengujian tersebut adalah sebagai berikut:

\section{a. Uji Konfirmatori Faktor Konstruk Eksogen}

Konstruk eksogen dalam penelitian ini terdisi dari dua konstruk yaitu kepemimpinan transformasional dan komitmen organisasi. Pengujian ini dilakukan setelah data terdistribusi secara normal pada saat responden berjumlah 137 responden. Berdasarkan hasil analisis konfirmatori nilai loading faktor dari semua indikator memiliki nilai di atas 0,5 yang artinya bahwa indikator tersebut valid menjelaskan variabel/konstruk yang ada. Terlihat juga nilai indeks kebaikan model menunjukkan nilai yang baik, dimana nilai chi-square, probabilitas, GFI, AGFI, TLI, CFI dan RMSEA menunjukkan nilai fit yaitu sesuai dengan yang direkomendasikan. Dengan demikian semua indikator dapat diterima.

Pengujian validitas dan reliabilitas konstruk eksogen selanjutnya adalah menghitung nilai reliabilitas konstruk (Construct Reliability) dan varians extract dari konstru eksogen sebagai berikut:

Hasil perhitungan menunjukkan bahwa Varians Extracted dan Construct Reliability sudah sesuai dengan yang dipersyaratkan (VE $>0,50$ dan $\mathrm{CR}>0,70$ ). Sehingga dapat ditarik kesimpulan bahwa konstruk eksogen yang terdiri dari variabel kepemimpinan transformasional dan komitmen organisasi sudah memenuhi kriteria yang dipersyaratkan. Artinya bahwa indikator-indikator yang membentuk variabel tersebut mampu atau valid menjelaskan konstruk yang ada.

\section{b. Uji Konfirmatori Faktor Konstruk Endogen}

Konstruk endogen dalam penelitian ini terdisi dari dua konstruk yaitu sharia engagement dan kinerja karyawan. Pengujian ini dilakukan setelah data terdistribusi secara normal pada saat responden berjumlah 137 responden.

Berdasarkan hasil analisis menunjukkan bahwa untuk konstruk sharia engagement nilai loading faktor indikator x12, x13, x14 
dan x15 nilainya dibawah yang direkomendasikan yaitu lebih kecil dari 0,5,akan tetapi karena konstruk ini merupakan konstruk baru yang sedang dikembangkan maka indikator-indikator tersebut tetap dipertahankan untuk dianalisis lebih lanjut. Hanya saja indikator x13 yang nilainya $-0,08$ terpaksa dikeluarkan dari analisis karena bernilai negatif.

Berdasarkan hasil perhitungan maka terlihat bahwa indeks kelayakan model menjadi lebih baik, nilai chi-square, probabilitas, GFI, AGFI, TLI, CFI dan RMSEA semuanya menunjukkan nilai fit yaitu sesuai dengan yang direkomendasikan. Sedangkan loading faktor untuk konstruk endogen yang mencakup variabel sharia engagement dan kinerja karyawan menunjukkan nilai lebih besar dari 0,5 , sesuai dengan yang dipersyaratkan. Dengan demikian semua indikator dapat diterima.

Pengujian validitas dan reliabilitas konstruk endogen selanjutnya adalah menghitung nilai reliabilitas konstruk (Construct Reliability) dan varians extract dari konstru eksogen sebagai berikut: Hasil peritungan menunjukkan bahwa Varians Extracted dan Construct Reliability sudah sesuai dengan yang dipersyaratkan (VE $>0,50$ dan CR $>0,70)$. Sehingga dapat ditarik kesimpulan bahwa konstruk endogen yang terdiri dari variabel sharia engagement dan kinerja karyawan sudah memenuhi kriteria yang dipersyaratkan. Artinya bahwa indikator-indikator yang membentuk variabel tersebut mampu atau valid menjelaskan konstruk yang ada.

\section{Evaluasi Persamaan Full Model}

Setelah dilakukan analisis konfirmatori dan indikatorindikator yang membentuk konstruk valid, langkah selanjutnya adalah melakukan estimasi model model full struktural. Proses dilakukan dengan melakukan pengembangan model atau merevisi model dengan menggunakan indikator-indikator yang telah diuji konfirmatori, datanya sudah terdistribusi secara normal serta indikator $\mathrm{x} 4$ yang didrop karena terindikasi terjadi crossloading factor.

Berdasarkan evaluasi model terhadap output full model SEM model penelitian empirik, dapat diambil kesimpulan mengenai hasil evaluasi model sebagai berikut: (1) Hasil uji analisis konfirmatori faktor telah memberi konfirmasi bahwasannya semua indikator- 
indikator variabel yang digunakan signifikan untuk membentuk variable. (2) Hasil uji Reliabilitas dan Validitas konstruk laten dengan menggunakan Construct Reliability dan Varians Extract menunjukkan bahwa: semua variabel laten yang digunakan dalam full model SEM model penelitian empirik valid dan reliable. (3) Hasil evaluasi asumsi SEM yang terdiri dari evaluasi kecukupan sampel, evaluasi normalitas dan evaluasi outlier, menunjukkan bahwasannya full model SEM model penelitian empirik telah memenuhi asumsi SEM. (4) Hasil uji kesesuaian dan uji statistik terhadap full model SEM model penelitian empirik menunjukkan bahwa keseluruhan model empirik yang diprediksi oleh peneliti fit (sesuai) dengan observasi atau model penelitian empirik dikategorikan fit atau baik. Parameter kesesuaian model chi-square, RMSEA, CMIN/DF, GFI, AGFI, TLI dan CFI, sudah memenuhi kriteria goodness of fit.

\section{Pengujian Hipotesis}

Pengujian hipotesis didasarkan pada output akhir full model SEM model empirik penelitian. Menurut Ferdinand (2011) regression weight memberikan besarnya nilai koefisien nilai unstandardized dan standardized untuk persamaan regresi OLS. Nilai CR adalah sama dengan nilai uji-t pada regresi OLS, sedangkan P adalah sama dengan tingkat probabilitas signifikansi. ${ }^{36}$ Berdasarkan tabel regression weight tersebut ditentukan diterima atau ditolaknya hipotesis atau hubungan antara kedua variabel laten yang bersangkutan.

Berdasarkan hasil analisis seperti yang disajikan pada tabel diatas menunjukkan bahwa Hipotesis 1, Hipotesis 3 dan Hipotesis 5 diterima, hal ini bisa dilihat dari nilai CR yang berada di atas persyaratan( $C R \geq 2,00)$. Sedangkan Hipotesis 2 dan hipotesis 4 ditolak, karena nilai $\mathrm{CR} \leq 2,00$.

Ditolaknya hipotesis 2 berarti bahwa komitmen organisasi tidak berpengaruh secara langsung terhadap kinerja karyawan berbeda dengan beberapa hasil penelitian terdahulu seperti penelitiannya Murty, W. A., \& Hudiwinarsih, G., (2012), (Sujana, E. (2012) dan Melina Taurisa, C., \& Intan, R. (2012), dimana para peneliti

${ }^{36}$ Ferdinand, A . Metode Penelitian Manajemen; Pedoman Penelitian Untuk Penulisan Skripsi, Tesis dan Disertasi Ilmu Manajemen. (Semarang : BP Universitas Diponegoro, 2011), h. 303. 
tersebut menghasilkan komitmen organisasi berpengaruh terhadap kinerja karyawan.

Demikian halnya dengan ditolaknya hipotesis 4 yang berarti bahwa kepemimpinan transformasional tidak berpengaruh secara langsung terhadap kinerja karyawan. Hasil penelitian ini berbeda dengan beberapa hasil penelitian terdahulu seperti penelitiannya Cavazotte et al., (2013), Sundi (2013), de Jong \& Bruch (2013), Carter et al., (2012 dan Weng et al.,(2011).

Ada beberapa kemungkinan ditolaknya hipotesis 2 dan 4 ini. Kemungkinan pertama berhubungan dengan obyek penelitian. Obyek penelitian yang berbeda memungkinkan hasil penelitian juga berbeda. Kedua, mungkin kurangnya konsistensi karyawan dalam dalam menjawab pertanyaan penelitian, takut pembalasan, bias, kurangnya komitmen, atau tidak ada hubungan. Dan kemungkinan ketiga, boleh jadi berhubungan dengan latar belakang pendidikan karyawan. Berdasarkan hasil penelitian menunjukkan bahwa sebanyak 93,22\% karyawan perbankan syariah merupakan lulusan perguruan tinggi umum dan hanya 6,78\% yang berpendidikan ilmu ekonomi syariah. Ada kemungkinan bahwa karyawan yang bekerja di perbankan syariah merupakan karyawan mutasi dari perbankan konvensional. Hasil ini mengandung pengertian bahwa sebagian besar karyawan di perbankan syariah cenderung berfikir pragmatis dan kecenderungan konvensionalnya masih tinggi. Oleh karenanya komitmen karyawan untuk menjalankan pekerjaan berdasarkan prinsip-prinsip masih kurang. Begitu juga dengan kepemimpinan yang ada di perbankan syariah. Berdasarkan hasil penelitian menunjukkan bahwa sebagaian besar pimpinan bank syariah berlatar belakang pendidikan umum dan merupakan mutasi dari bank konvensional. Ketika pimpinan mengaplikasikan gaya kepemimpinan transformasional justru megakibatkan perilaku yang kurang simpatik dari bawahan, karena bawahan mengetahui bahwa pimpinan mereka bukanlah orang yang menguasai konsep syariah dengan baik.

\section{Analisis Pengaruh Langsung, Tidak Langsung dan Total}

Pengaruh langsung (direct effect) tidak lain adalah koefisien dari semua garis koefisien dengan anak panah satu ujung, sedang pengaruh tidak langsung merupakan pengaruh yang diakibatkan 
oleh variabel antara sedangkan pengaruh total merupakan hasil penjumlahan dari pengaruh langsung dan tidak langsung. Berdasarkan hasil pengolahan dengan program AMOS, besarnya pengaruh ini bisa dilihat dari Standardized Direct Effects, Standardized Indirect Effects dan Standardized Total Effects

Membangun kekuatan nilai sharia engagement dapat meningkatkan kinerja karyawan. Sharia engagement dibagun melalui penerapan tipe kepemimpinan transformasional dan komitmen organisasi dari karyawan di perbankan syari'ah. Secara lebih rinci dijelaskan sebagai berikut:

Pertama, sharia engagement dipengaruhi langsung oleh komitmen organisasi sebesar 0,362 dan dipengaruhi langsung oleh kepemimpinan transformasional sebesar 0,258. Oleh karena itu perbankan syariah perlu menerapkan tipe kepemimpinan transformasional dan membangkitkan kesadaran karyawan untuk meningkatkan komitmen pada organisasi.

Kedua, kinerja karyawan dipengaruhi secara tidak langsung oleh komitmen organisasi dan kepemimpinan transformasional. Besarnya pengaruh tidak langsung tersebut masing-masing sebesar 0,322 dan 0,229. Berdasarkan hasil uji hipotesis yang dibahas pada bagian sebelumnya juga menunjukkan bahwa kepemimpinan transformasional dan komitmen organisasi tidak bisa mempengaruhi kinerja karyawan secara langsung, tetapi terlebih dahulu harus dibangun keterlibatan kerja secara syari'ah (sharia engagement). Ketika sharia engagement terbentuk, kepemimpinan transformasional dan komitmen organisasi bisa meningkatkan kinerja karyawan. Hal ini berarti bahwa kepemimpinan transformasional bisa mempengaruhi kinerja karyawan melalui sharia engagement dan komitmen organisasi juga bisa meningkatkan kinerja karyawan melalui sharia engagement. Berdasarkan tabel di atas juga menunjukkan bahwa sharia engagement bisa mempengaruhi langsung kinerja karyawan sebesar 0,890. Hal ini menunjukkan bahwa kekuatan nilai sharia engagement dapat meningkatkan kinerja lebih tinggi. Besar pengaruh hubungan antara kedua variabel ini juga lebih besar dari pengaruh hubungan antar variabel lainnya yang diteliti dalam penelitian ini. 


\section{Sharia Engagement dan pemberdayaan Masyarakat}

Perbankan merupakan lembaga yang sangat vital bagi keberlangsungan kehidupan masyarakat modern sekarang ini, sebab sebagian besar transaksi masyarakat saat ini hampir selalu menggunakan jasa layanan perbankan baik itu untuk layanan jasa, simpan pinjam dan keperluan sosial lainnya. Munculnya perbankan syariah di awal-awal tahun 1990-an menjadi alternatif baru bagi masyarakat Indonesia, khusunya masayarakat Muslim yang pada masa itu masih ragu dalam bertransaksi menggunakan layanan perbankan. Dengan hadirnya bank syariah, maka kebutuhan masyarakat muslim yang memiliki komitmen kuat akan ajaran-ajaran agamanya secara formal telah terpenuhi.

Tetapi setelah hampir 25 tahun beroperasi, pertumbuhan perbankan syariah belum menunjukkan perkembangan yang menggembirakan, hingga akhir tahun 2016, market share perbankan syariah baru mencapai 5,2\% jauh dari target $20 \%$ seperti yang diharapkan pada awal-awal pendiriannya. Dan berdasarkan beberapa hasil penelitian menunjukkan bahwa lambatnya perkembangan bank syariah di negara yang pendudukanya mayoritas muslim disebabkan oleh masih kuatnya anggapan masyarakat yang menilai bahwa tidak ada bedanya antara bank syariah dengan bank konvensional. Anggapan sebagian besar masyarakat muslim ini tentu saja tidak timbul dengan sendirinya, akan tetapi diakibatkan oleh beberapa hal yang melatarbelakanginya, seperti kurangnya pengetahuan, kebiasaan bertransaksi di bank konvensional, dan kurangnya kompetensi karayawan bank syariah yang sebagian besar merupakan mutasi dari bank konvensional atau tidak memiliki latarbelakang pendidikan keuangan syariah. Hasil dari penelitian ini menunjukkan bahwa hampir 90\% karyawan bank syariah tidak memiliki latar belakang pendidikan ekonomi islam atau yang sejenisnya, sebab para karyawan tersebut sebagian besar merupakan mutasi dari bank konvensional induk yang sebelumnya menaungi bank syariah yang bersangkutan.

Akibat dari ketidakkompetenan karyawan akan nilainilai syariah dalam transaksi dan akad-akad di bank syariah, maka timbulah anggapan dan judgment yang kurang postitif dari masyarakat muslim sendiri. Masyarakat muslim yang sebelumnya 
antusias dengan hadirnya bank syariah berbalik arah menjadi skeptis dan bahkan apatis akan kesyariahan bank syariah itu sendiri, sehingga perkembangan bank syariah yang sudah hampir 3 dekade ini tidak sesuai dengan yang diharapkan.

Hasil penelitian menunjukkan gejala yang sama dengan penelitian-penelitian sebelumnya, sehingga perlu kiranya keterkaitan kerja berdasarkan syariah untuk selalu dipraktikkan dan dijadikan kebiasaan bagi para pimpinan dan karyawan syariah. Sebab lahirnya bank syariah adalah untuk memperbaiki dan mengganti praktikpraktik yang ada di bank konvensional yang dianggap tidak adil, dzolim dan tidak sesuia dengan ajaran agama Islam yang rahmatan lil alamin.

Konsep-konsep Islam dalam ekonomi dan keuangan sangat baik dan ideal untuk diterapkan, misalnya konsep kerjasama (mudharabah dan musyarakah), konsep jual beli dengan margin yang disepakati di awal (murabahah, salam dan istishna') semuanya merupakan konsep transaksi ekonomi yang menjunjung nilai-nilai keadilan dan kebenaran. Sehingga apabila konsep-konsep tersebut diterapkan dengan benar oleh orang-orang yang kompeten maka perbankan syariah akan menjadi ujung tombak terdepan dalam upaya pemberdayaan masyarakat di Indonesia.

\section{E. Simpulan}

Penelitian ini menghasilkan bahwa Hipotesis 1, Hipotesis 3 dan Hipotesis 5 diterima, sedangkan hipotesis 2 dan hipotesis 4 ditolak. Ada beberapa kemungkinan ditolaknya hipotesis 2 dan 4 ini. Kemungkinan pertama berhubungan dengan obyek penelitian. Obyek penelitian yang berbeda memungkinkan hasil penelitian juga berbeda. Kedua, kurangnya konsistensi karyawan dalam dalam menjawab pertanyaan penelitian, dengan berbagai factor alasan. Ketiga, berhubungan dengan latar belakang pendidikan karyawan. Berdasarkan hasil penelitian menunjukkan bahwa sebanyak 93,22\% karyawan perbankan syariah merupakan lulusan perguruan tinggi umum dan hanya 6,78\% yang berpendidikan ilmu ekonomi syariah. Ada kemungkinan bahwa karyawan yang bekerja di perbankan syariah merupakan karyawan mutasi dari perbankan konvensional. 
Hasil ini mengandung pengertian bahwa sebagian besar karyawan di perbankan syariah cenderung berfikir pragmatis dan kecenderungan konvensionalnya masih tinggi. Oleh karenanya komitmen karyawan untuk menjalankan pekerjaan berdasarkan prinsip-prinsip masih kurang. Begitu juga dengan kepemimpinan yang ada di perbankan syariah. Berdasarkan hasil penelitian menunjukkan bahwa sebagaian besar pimpinan bank syariah berlatar belakang pendidikan umum dan merupakan mutasi dari bank konvensional. Ketika pimpinan mengaplikasikan gaya kepemimpinan transformasional justru megakibatkan perilaku yang kurang simpatik dari bawahan, karena bawahan mengetahui bahwa pimpinan mereka bukanlah orang yang menguasai konsep syariah dengan baik.Hasil penelitian ini berhasil membuktikan pentingnya perbankan syariah untuk mengaplikasikan konsep sharia engagement.

Berdasarkan hasil penelitian menunjukkan bahwa komitmen organisasi dan kepemimpinan transformasional tidak bisa mempengaruhi kinerja karyawan secara langsung. Tetapi manakala hubungan ini dimediasi oleh sharia engagement hubungan komitmen organisasi dan kinerja karyawan positif signifikan, begitu juga dengan hubungan antar kepemimpinan transformasinal dengan kinerja karyawan.

Hasil penelitian ini juga berhasil memberi solusi masalah penelitian bahwa kurangnya kompetensi karyawan perbankan syariah dalam ilmu syariah, bisa diatasi dengan mengaplikasikan konsep sharia engegement. Keterlibatan karyawan dalam sharia engegement akan meningkatkan kompetensi syari'ah yang dimiliki karyawan, yang dampak selanjutnya meningkatkan kinerja karyawan perbankan syaria'ah. 


\section{REFERENSI}

Albdour, A. A., \& Altarawneh, I. I. (2014). Employee engagement and organizational commitment: Evidence from Jordan. International Journal of Business, 19(2), 192.

Bass, B. M. (1985). Leadership and performance beyond exceptions. New York: Free Press.

Benkhoff, B. (1997). Ignoring commitment is costly: New approaches establish the missing link between commitment and performance. Human Relation, June 1997, Volume 50, Issue 6, pp 701-726. Diunduh dari: http://link.springer.com/article

Bernadin, H. John and Joyce E.A Russel, 1993, Human Resources Management, Mc.Graw Hill, Inc. Singapore

Breevaart, K., Bakker, A. B., Demerouti, E., Sleebos, D. M., \& Maduro, V. (2014). Uncovering the underlying relationship between transformational leaders and followers' task performance. Journal of Personnel Psychology.

Breevaart, K., Bakker, A., Hetland, J., Demerouti, E., Olsen, O. K., \& Espevik, R. (2014). Daily transactional and transformational leadership and daily employee engagement. Journal of occupational and organizational psychology, 87(1), 138-157

Carter, M. Z., Armenakis, A. A., Feild, H. S., \& Mossholder, K. W. (2012). Transformational leadership, relationship quality, and employee performance during continuous incremental organizational change. Journal of Organizational Behavior, 30(July), 839-862. http://doi.org/10.1002/job

Cavazotte, F., Moreno, V., \& Bernardo, J. (2013). Transformational leaders and work performance: The mediating roles of identification and self-efficacy. BAR - Brazilian Administration Review, 10(4), 490-512. http://doi.org/10.1590/S180776922013000400007

De Jong, S. B., \& Bruch, H. (2013). the Importance of a Homogeneous Transformational Leadership Climate for Organizational Performance. International Journal of Leadership Studies, 8(1), 1-18. Retrieved from http:/ / search.ebscohost.com/login.aspx? direct $=$ true $\& d b=b$ th $\& A N=92582222 \&$ site $=$ bsi-live $\&$ scope $=$ site 
Dumdum, U. R., Lowe, K. B., \& Avolio, B. J. (2013). A meta-analysis of transformational and transactional leadership correlates of effectiveness and satisfaction: An update and extension. In Transformational and Charismatic Leadership: The Road Ahead 10th Anniversary Edition (pp. 39-70). Emerald Group Publishing Limited.

Ferdinand, A (2011). Metode Penelitian Manajemen; Pedoman Penelitian Untuk Penulisan Skripsi, Tesis dan Disertasi Ilmu Manajemen, Badan Pnerbit UNDIP, Semarang

Ferdinand, A. (2005., “Structural Equation Modeling Dalam Penelitian Manajemen", Badan Penerbit UNDIP, Semarang

Ghozali, Imam,(2011) Aplikasi Analisis Multivariate Dengan Program SPSS. Semarang : BP Universitas Diponegoro.

Halbesleben, J. R. B., \& Wheeler, A. R. (2008). The relative roles of engagement and embeddedness in predicting job performance and intention to leave. Work \& Stress, Vol. 22, No. 3, JulySeptember 2008, 24225. Diunduh dari: www. tandfoneline.com

Harter, J. K., Schmidt, F. L., \& Hayes, T. L.(2002). Business-unitlevel relationship between employee satisfaction employee engagement, and business outcomes: A meta-analysis. Journal of Applied Psychology, 87, 268-279.

Jamie A. Gruman Alan M. Saks. (2009). Performance management and employee engagement, Human Resource Management Review, 21 (2011), 123-136. Diunduh dari: www.sciendirect. com

Macey, W. H., Schneider, B., Barbera, K. M., and Young, S. A. (2009), Employee engagement: Tools for analysis, practice, and competitive advantage, Personnel Psychology, Volume 65, Issue 1, pages 207-210, Spring 2012. Diunduh dari: http://onlinelibrary.wiley.com/doi/10.1111/j.17446570.2011.01242_3.x/pdf

Mangundjaya, W. L. (2012). are organizational commitment and employee engagement important in achieving 
individual readiness for change?.humanitas (Jurnal Psikologi Indonesia), 9(2).

Melina Taurisa, C., \& Intan, R. (2012). Analisis pengaruh budaya organisasi dan kepuasan kerja terhadap komitmen organisasional dalam meningkatkan kinerja karyawan (Studi pada PT. Sido Muncul Kaligawe Semarang). Jurnal Bisnis dan Ekonomi, 19(2).

Morrison, E. W. (1994). Role definitions and organizational citizenship behavior: The importance of the employee's perspective. Academy of Management Journal. Diunduh dari: http:/ / amj.aom.org/content

Mowday, R. T., Porter, L. W., \& Steers, R. M. (2013). Employeeorganization linkages: The psychology of commitment, absenteeism, and turnover. Academic press.

Murty, W. A., \& Hudiwinarsih, G. (2012). Pengaruh kompensasi, motivasi dan komitmen organisasional terhadap kinerja karyawan bagian akuntansi (studi kasus pada perusahaan manufaktur di Surabaya). The Indonesian Accounting Review, 2(02), 215-228.

Murty, W. A., \& Hudiwinarsih, G. (2012). Pengaruh kompensasi, motivasi dan komitmen organisasional terhadap kinerja karyawan bagian akuntansi (studi kasus pada perusahaan manufaktur di Surabaya). The Indonesian Accounting Review, 2(02), 215-228.

Nawawi, Hadari., 1997, Manajemen Sumber Daya Manusia untuk Bisnis yang Kompetitif, Gajah Mada University Press, Yogyakarta.

Nik, M., Ab. Rahman, M. Nordin, S. Abdullah.(2004). The relationship between Islamic work ethics and organizational commitment: A case analysis. Malaysian Management. Diunduh dari: http:/ / etd.uum.edu.my/2291/2/1.Haytham_S._D._Al_Kilani. pdf

Nohria, N., Groysberg, B., \& Lee, L. (2008). Employee motivation: A powerful new model. Harvard Business Review, 86, 78-84. Diunduh dari: www.homeworkmarket.com 
Northouse, P. G. (2004) Leadership theory and practice (3rd ed.). Thousand Oaks, CA: Sage. Diunduh dari: www.google.com/ book

Raja, M.W. (2012). Does Transformational Leadership Leads To Higher Employee Work Engagement, A Study of Pakistani Service Sector Firms. International Journal of Academic Research in Business and Social Sciences, Vol. 2, No. 1. Diunduh dari: http:/ / www.hrmars.com/admin/pics/465.pdf

Robinson, D., Perryman, S. and Hayday, S. (2007). The Drivers of Employee Engagement. Brighton, Institute for Employment Studies. Diunduh dari: http://www.employment-studies. co.uk/system/files/resources/files/op11.pdf

Rusdianti, E. (2013). Membangun Pertautan Syariah Kaitannya Dengan Peningkatan Kinerja Karyawan. Disertasi, Universitas Diponegoro, Semarang

Solomon Markos and M. Sandhya Sridevi. (2010). EmployeeEngagement: The Key to Improving Performance. International Journal of Business and Management. Diunduh dari: http://www.ccsenet.org/journal/index.php/ijbm/article/ viewFile/6745/6332

Sugiono, (2012) Statitika untuk Penelitian, Bandung: Alfabeta

Sundi, K. (2013). Transformational Leadership and Transactional Leadership on Employee Performance of Konawe Education Department at Southeast Sulawesi Province. International Journal of Business and Management Invention, 2(12), 50-58. Retrieved from http://www.ijbmi.org/papers/Vol(2)12/ Version-1/F021201050058.pdf

Wang, G., Oh, I. S., Courtright, S. H., \& Colbert, A. E. (2011). Transformational leadership and performance across criteria and levels: A meta-analytic review of 25 years of research. Group $\mathcal{E}$ Organization Management, 36(2), 223-270.

Weng, L., Su, C., \& Lai, Y. (2011). Superior Service Performance through Transformational Leadership : A Cross-level Study of a Large Taiwanese Commercial Bank. Asia Pacific Management Review, 16(2), 181-195. 
Xanthopoulou, D., Bakker, A. B., Heuven, E., Demerouti,E., \& Schaufeli, W. B. (2008). Working in the sky: A diary study on work engagement among flight attendants. Journal of Occupational Health Psychology, Vol. 13, No. 4, 345-356. Diunduh dari: http://repub.eur.nl/pub 